\title{
Energy metabolism in women during short exposure to the thermoneutral zone
}

Citation for published version (APA):

Westerterp-Plantenga, M. S., van Marken Lichtenbelt, W. D., Cilissen, C., \& Top, S. (2002). Energy metabolism in women during short exposure to the thermoneutral zone. Physiology \& Behavior, 75(1-2), 227-235. https://doi.org/10.1016/S0031-9384(01)00649-7

Document status and date:

Published: 01/01/2002

DOI:

10.1016/S0031-9384(01)00649-7

Document Version:

Publisher's PDF, also known as Version of record

Document license:

Taverne

Please check the document version of this publication:

- A submitted manuscript is the version of the article upon submission and before peer-review. There can be important differences between the submitted version and the official published version of record.

People interested in the research are advised to contact the author for the final version of the publication, or visit the DOI to the publisher's website.

- The final author version and the galley proof are versions of the publication after peer review.

- The final published version features the final layout of the paper including the volume, issue and page numbers.

Link to publication

\footnotetext{
General rights rights.

- You may freely distribute the URL identifying the publication in the public portal. please follow below link for the End User Agreement:

www.umlib.nl/taverne-license

Take down policy

If you believe that this document breaches copyright please contact us at:

repository@maastrichtuniversity.nl

providing details and we will investigate your claim.
}

Copyright and moral rights for the publications made accessible in the public portal are retained by the authors and/or other copyright owners and it is a condition of accessing publications that users recognise and abide by the legal requirements associated with these

- Users may download and print one copy of any publication from the public portal for the purpose of private study or research.

- You may not further distribute the material or use it for any profit-making activity or commercial gain

If the publication is distributed under the terms of Article $25 \mathrm{fa}$ of the Dutch Copyright Act, indicated by the "Taverne" license above, 


\title{
Energy metabolism in women during short exposure to the thermoneutral zone
}

\author{
M.S. Westerterp-Plantenga*, W.D. van Marken Lichtenbelt, C. Cilissen, S. Top \\ Department of Human Biology, University of Maastricht, P.O. Box 616, 6200 MD Maastricht, The Netherlands
}

Received 30 May 2001; received in revised form 15 August 2001; accepted 30 October 2001

\begin{abstract}
Ambient temperature has been shown to affect energy metabolism in field situations. Therefore, we assessed the effect of a short exposure to the thermoneutral zone, i.e., $27^{\circ} \mathrm{C}\left(81^{\circ} \mathrm{F}\right)$, in comparison to the usual ambient temperature of $22{ }^{\circ} \mathrm{C}\left(72{ }^{\circ} \mathrm{F}\right)$, on energy expenditure $(\mathrm{EE})$, substrate oxidation, and energy intake (EI) in a controlled situation. Subjects, i.e., women (ages $22 \pm 2$ years, BMI $22 \pm 3,28 \pm 4 \%$ body fat), stayed in a respiration chamber three times for $48 \mathrm{~h}$ each: once at $22^{\circ} \mathrm{C}$, and twice at $27{ }^{\circ} \mathrm{C}$ in random order, wearing standardized clothing, executing a standardized daily-activities protocol, and being fed in energy balance (EB). During the last $24 \mathrm{~h}$ at $22{ }^{\circ} \mathrm{C}$, and once during the last $24 \mathrm{~h}$ at $27{ }^{\circ} \mathrm{C}$, they were fed ad libitum. At $27^{\circ} \mathrm{C}$, compared to at $22^{\circ} \mathrm{C}$, EE was $8.9 \pm 1.3 \mathrm{MJ} /$ day vs. $9.9 \pm 1.5 \mathrm{MJ} / \mathrm{day}(P<.001)$ due to decreases in diet-induced thermogenesis (DIT) and activity-induced energy expenditure (AEE) $(P<.01)$; respiratory quotient (RQ) had increased $(P<.05)$; core $(P<.05)$ and skin $(P<.001)$ temperatures had increased. During ad lib feeding, EI was $90-91 \%$ of EE $(P=.9)$, due to changes in energy density (ED) of the food choice $(P<.01)$, and related to changes in body temperature and EE $(P<.001)$. Thus, at $27{ }^{\circ} \mathrm{C}$, compared to $22{ }^{\circ} \mathrm{C}$, energy metabolism was reduced by reductions in DIT and in AEE, while RQ was increased. Reduction in EI was primarily related to body temperature changes and secondarily to changes in EE. C 2002 Elsevier Science Inc. All rights reserved.
\end{abstract}

Keywords: Ambient temperature; Body temperature; Energy expenditure; Substrate oxidation; Energy intake; Energy density; Appetite; Humans

\section{Introduction}

Ambient temperature has been shown to affect energy metabolism in field situations. In this controlled study, we addressed the questions whether ambient temperature in the zone of thermoneutrality $27{ }^{\circ} \mathrm{C}\left(81{ }^{\circ} \mathrm{F}\right)$ affects energy metabolism under energy balance (EB) conditions, and energy intake (EI) under ad lib feeding conditions, as compared to the temperature the subjects were acclimated to, namely, $22{ }^{\circ} \mathrm{C}\left(72{ }^{\circ} \mathrm{F}\right) .22{ }^{\circ} \mathrm{C}$ is the normal temperature in the rooms and buildings in The Netherlands. Within a certain range of ambient temperatures, homeotherms, e.g., humans, have a relatively constant core body temperature [1-6] that represents the temperature of deep thermosensitive units and the thermal mass of the body core [7]. The skin temperature varies relatively more with the temperature

\footnotetext{
* Corresponding author. Tel.: +31-43-3881617; fax: +31-43-3670976.

E-mail address: m.westerterp@hb.unimaas.nl (M.S. WesterterpPlantenga).
}

of the environment and with metabolic rate than the core temperature does. It contributes to the control of skin blood flow in neutral and warm conditions thus influencing the effective thickness of the body 'shell' according to the core-shell concept $[3,8,9]$. A significant relationship between body temperature and average daily metabolic rate [4,10-12], as well as between ambient temperature and metabolic rate, has been shown. In older [13-17] and more recent studies [18-20], an inverse relationship between heat production or metabolic rate and ambient temperatures between 10 and $30{ }^{\circ} \mathrm{C}$ was shown. Changes in energy metabolism related to the actual ambient temperature in homeotherms, e.g., humans, were observed as changes in total or in basal metabolic rate (BMR). Effects on activityinduced energy expenditure (AEE) [21] and diet-induced thermogenesis (DIT) [22] only have been dealt with independently. The aim of the present study was to highlight EB in women exposed to the thermoneutral zone, in comparison to the usual temperature in the buildings, i.e., the temperature they were acclimated to, wearing 0.6 clo of insulation. EB was assessed in a behavioral-physiological way. The 
relationship between a physiological response (energy expenditure $[\mathrm{EE}]$ and core skin temperature gradient controlled for clothing and daily physical activities) and a behavioral response (the appetite profile and ad libitum food intake) to an elevated ambient temperature was assessed. The interesting part of this possible relationship is the question whether ad libitum food intake is primarily related to ambient temperature, thus to the core-skin temperature gradient of the body, or to EE. The present study addresses the effect of a short-term exposure to the thermoneutral zone $27{ }^{\circ} \mathrm{C}\left(81{ }^{\circ} \mathrm{F}\right)$ in a well-controlled but relatively normal situation on total $\mathrm{EE}$ and on the separate components of it at the same time, in EB conditions. To study AEE in the thermoneutral zone, it was necessary for the daily physical activities to follow a standardized protocol. Studying DIT in the thermoneutral zone also necessitates accounting for possible EI adaptation [23-26]. Furthermore, a possible effect on substrate oxidation was assessed. In addition to assessing the effect of a change in ambient temperature on EE, we measured the effect on EI under ad libitum conditions at the same time. With respect to the relationship between food intake and ambient temperature, increased ambient temperature is generally considered to inhibit appetite. Although LeBlanc [27] reports no change, Edholm and Goldsmith [28], in a study of physically active acclimatized and unacclimatized soldiers deployed to a cold environment, found food consumption increased with exposure to cold climate. Johnson and Kark [29] showed EI decreases with increasing average local temperature. While assessing the possible change in EI in humans in response to short-term exposure to an elevated ambient temperature, we took the possible changes in EE into account, by assessing the EE while the subjects were fed in EB separately, as mentioned above. At both temperatures, daily physical activities and clothing were the same for all subjects and at each occasion. We hypothesized that both expenditure and intake of energy would decrease in the zone of thermoneutrality, in comparison with energy metabolism below the zone of thermoneutrality, at the temperature the subjects were acclimated to.

\section{Methods}

\subsection{Subjects}

Eight healthy female volunteers participated in this study. They were recruited from the University staff and students. Physical characteristics [mean; S.E.M.: age (years) 22.6; 1.8, height $(\mathrm{m}) 1.69 ; 0.06$, weight $(\mathrm{kg}) 63.9$; 11.0, BMI $\left(\mathrm{kg} / \mathrm{m}^{2}\right) 22.2 ; 3.2$, body fat $\% 27.8 ; 4.4$, fat-free mass (FFM) (kg) 48.1; 5.8] show that all subjects were normal in weight. Body composition was determined in the fasted state by hydrodensitometry with simultaneous assessment of the residual lung volume by a helium dilution technique. Percentage body fat was calculated using the equation of Siri [30]. Scores on the Three Factor

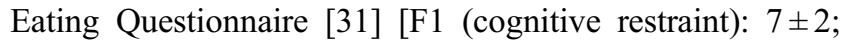
F2 (disinhibition or emotional eating): $5 \pm 3$; F3 (hunger): $5 \pm 2$ ] showed that the subjects were dietary unrestrained, with normal values for disinhibition or emotional eating and hunger, relative to our population [32]. Exclusion criteria were: medication, intensive sports activities $(>4$ times a week), smoking, unhealthy with respect to blood pressure, diabetes, other illnesses, being overweight or obese, dietary restraint. The subjects were asked which percentage of time they usually spend inside and outside buildings, and the temperature of the buildings they usually live and work in. Only one gender was chosen to limit the number of subjects. The subjects were informed on the nature of the experiment, especially on what to expect from staying in a respiration chamber. The chamber was shown to them before the experiment, and the principle of the measurements was explained to them. They were required to follow the detailed instructions on clothing, time schedule, daily activities, meals and snacks, rating of questionnaires as described below. All subjects signed an informed consent for the study protocol, which was approved by the Medical Ethics Committee of the University of Maastricht. The motivation for participation of the subjects was scientific interest; this was the first time such a study was performed in the respiration chambers at the University of Maastricht. As such, the subjects were not naïve in regard to the nature of the research, but we all were naïve in regard to the expected outcomes.

\subsection{Protocol}

The study took place at the Department of Human Biology, University of Maastricht. Subjects stayed three times for $48 \mathrm{~h}$ each $(21: 00-21: 00 \mathrm{~h})$ in the respiration chamber; once at the acclimation temperature, i.e., $22{ }^{\circ} \mathrm{C}$ $\left(72{ }^{\circ} \mathrm{F}\right)$, and twice in the thermoneutral zone, i.e., $27{ }^{\circ} \mathrm{C}$ $\left(81^{\circ} \mathrm{F}\right)$; the three sessions were performed in random order, with 4 weeks in between the sessions. At $22{ }^{\circ} \mathrm{C}$ and once at $27{ }^{\circ} \mathrm{C}$, subjects were fed in EB on the first day, and ad libitum on the second day. During the other 2 days at $27{ }^{\circ} \mathrm{C}$, they were fed in EB. This experimental set-up allowed one habituation day, both times at $27{ }^{\circ} \mathrm{C}$. The second days at $27{ }^{\circ} \mathrm{C}$ could then be used for comparisons: one for $\mathrm{EE}$ and one for EI. The acclimation temperature of $22{ }^{\circ} \mathrm{C}$ was based upon the usual environment the subjects. They were living in centrally heated houses $\left(22-23{ }^{\circ} \mathrm{C}\right)$, and working in centrally heated buildings $\left(22{ }^{\circ} \mathrm{C}\right)$. They reported spending $6-12 \%$ of their waking time during the working days of the week outside, by cycling to and from work, and shopping. At that time of the year, outside temperature was $10 \pm 2{ }^{\circ} \mathrm{C}$, and the insulation of outdoor clothing was $1.6 \pm 0.2$ clo [35]. Each time a subject stayed in the chamber, she was in the same phase of her menstrual cycle, to avoid possible effects of menstrual cycle phases on EE. Thus, a within-subject design was applied. 


\subsection{Respiration chamber}

The respiration chambers consist of two adjoining $14 \mathrm{~m}^{3}$ rooms, each furnished with a bed, chair, television, radio, telephone, intercom, computer, wash bowl, and deep freeze toilet. The chambers give the impression of a normal living room. For each experiment, two subjects are present at the same time, one in each room. Communication between the subjects and investigator is possible via an intercom or telephone. Visual contact is also possible through a window in the door and between the two chambers. A third window provides outside view. Three air locks provide passage for the exchange of food, collection of urine, and for sampling of blood. During the experiment, the temperature as well as the relative humidity $(55 \% \mathrm{rh})$ was almost constant in the chamber, at 22 or $27{ }^{\circ} \mathrm{C}$, during day and night. The measured temperature varied between 21.9-22.1 and $26.9-27.1{ }^{\circ} \mathrm{C}$, respectively. The variation in relative humidity was $53-55 \% \mathrm{rh}$ [33]. Physical activity was monitored by means of a radar system, based on the Doppler principle [33], validated by Bouten et al. [34].

\subsection{Outfit}

Subjects were required to wear the same outfit three times: underwear, bermuda shorts, two T-shirts, and a pair of sport shoes during the day (insulation 0.6 clo [35]). At night, subjects wore one T-shirt and they slept under a cotton sheet and a light duvet $\left(375 \mathrm{~g} / \mathrm{m}^{2}\right)$. The clothing was tried out before the protocol began to assure comfort at $27^{\circ} \mathrm{C}$ as well as at $22{ }^{\circ} \mathrm{C}$. The subjects received instructions on the clothing beforehand. It was explained to them that they had to wear the same outfit every time in order to allow us to compare exposure to two different ambient temperatures, without possible behavioral adaptation to ambient temperature by means of clothing.

\subsection{Body weight measurement and daily-activities protocol}

Body weight was determined on a digital scale, accurate to the nearest $0.1 \mathrm{~kg}$, at the start and at the end of each session, at 21:00 h. Moreover, subjects were instructed to weigh themselves in the chamber, every morning in the fasting state, after voiding.

They were also instructed to follow a standard dailyactivities protocol, which described every hour, and sometimes every $15 \mathrm{~min}$, what the subjects were supposed to do. It included household activities, standardized extensive aerobic exercise, refreshing, and sedentary activities such as reading and watching television. The meal and snack times were standardized. The aerobic exercise was standardized by consistently using the same music with a fixed rhythm from a radio-cassette, while the subjects performed the same step test (alternating 5 min stepping, 5 min sitting), during $30 \mathrm{~min}$, once in the morning and once in the afternoon, controlled by the experimenter.

\subsection{Body temperature}

Subjects' skin temperatures were registered continuously from 8:00 a.m. to 12:00 p.m. by means of a thermistor surface contact probe (YSI Series 400 probes; accuracy $\pm 0.01{ }^{\circ} \mathrm{C}$ ) fixed to the skin with thin, air-permeable adhesive surgical tape. Proximal skin temperatures were measured at the forehead, thigh, and the infraclaviculaire zone; distal skin temperatures were measured at the hand and foot. Core temperature was measured rectally, from 00:00 h till 8:00 a.m., by means of a similar thermistor probe (YSI Series 400 , accuracy $\pm 0.1^{\circ} \mathrm{C}$ ); insertion was $4 \mathrm{~cm}$. During the day, rectal temperature was measured using a conventional digital thermometer (Philips HP 5315, accuracy $0.1{ }^{\circ} \mathrm{C}$ ); insertion was $10 \mathrm{~cm}$. Temperature measurements were thoroughly explained to the subjects, and they were trained in the preprotocol phase in order to obtain reproducible measurements, before entering the respiration chambers. The thermometric probes were calibrated to within $0.05{ }^{\circ} \mathrm{C}$ in a water bath against a reference mercury thermometer (accuracy $\pm 0.02{ }^{\circ} \mathrm{C}$ ).

\subsection{Energy expenditure}

Subjects' EE was calculated from oxygen consumption and carbon dioxide production $[33,36]$. The respiration chamber was ventilated with fresh air at a rate of 70-80 1/min. A dry gas meter (G4 Schlumberger, The Netherlands) measured the ventilation rate. A paramagnetic $\mathrm{O}_{2}$ analyzer (OA 184A, Servomex) and an infrared $\mathrm{CO}_{2}$ analyzer(Uras 3G, Hartmann and Braun) were used to analyze the samples of the in- and outgoing air. Ingoing air was analyzed once every $15 \mathrm{~min}$ and outgoing air every $5 \mathrm{~min}$ [33].

\subsection{Energy intake}

Subjects' appetite and EI were determined as follows. At $22{ }^{\circ} \mathrm{C}$ and once at $27^{\circ} \mathrm{C}$, subjects were fed in EB during the first $24 \mathrm{~h}$, and ad libitum during the second $24 \mathrm{~h}$. The other time the subjects stayed at $27{ }^{\circ} \mathrm{C}$, they were fed in $\mathrm{EB}$ throughout the $48 \mathrm{~h}$. Feeding in EB took place by estimating EE by means of the Harris-Benedict equation [37], which gives the BMR, and multiplying the BMR by an estimated physical activity level (PAL) of 1.65 [38]. After measuring EE, this estimation was adjusted to the realistic BMR and PAL. Thus, energy requirement was calculated for each subject individually. Based upon this, the meals and snacks were prepared (three meals and three snacks per day, which was on average the subjects' habitual food intake pattern), using comparable food items each day, which also belonged to the subjects' habitual diets. Breakfast consisted of whole wheat bread $(10.5 \mathrm{~kJ} / \mathrm{g})$, apricot jam and blueberry jam $(10.2 \mathrm{~kJ} / \mathrm{g})$, sweet spicy biscuit $(20.5 \mathrm{~kJ} / \mathrm{g})$, coffee (decaffeinated), tea, or water $(0 \mathrm{~kJ} / \mathrm{g})$. Snacks were chocowafer cookies $(20.2 \mathrm{~kJ} / \mathrm{g})$, wheat cookies $(17.3 \mathrm{~kJ} / \mathrm{g})$, cake $(17.6 \mathrm{~kJ} / \mathrm{g})$, and unsweetened orange juice $(1.6 \mathrm{~kJ} / \mathrm{g})$, fruit 
(apple $2.1 \mathrm{~kJ} / \mathrm{g}$, banana $3.8 \mathrm{~kJ} / \mathrm{g}$, kiwi $1.7 \mathrm{~kJ} / \mathrm{g}$, mandarin orange $2.0 \mathrm{~kJ} / \mathrm{g})$, paprika crisps and salt crisps $(22.6 \mathrm{~kJ} / \mathrm{g})$. Lunch consisted of lasagna bolognaise, macaroni with cheese and ham or nasi goreng (all $5.4 \mathrm{~kJ} / \mathrm{g}$ ), water, vanilla ice cream $(5.1 \mathrm{~kJ} / \mathrm{g})$, milk chocolate $(22.5 \mathrm{~kJ} / \mathrm{g})$, water. Dinner consisted of toast or sandwich $(15.3 \mathrm{~kJ} / \mathrm{g})$ with Gouda cheese $48+(16.4 \mathrm{~kJ} / \mathrm{g})$, ham $(5.7 \mathrm{~kJ} / \mathrm{g})$, salad $0.3 \mathrm{~kJ} / \mathrm{g}$, tomato $(0.5 \mathrm{~kJ} / \mathrm{g})$, full fat fruit yogurt or vanilla dessert $(3.9 \mathrm{~kJ} / \mathrm{g})$, and water.

All food items were checked for hedonic values beforehand, and only the ones that were liked by all subjects [Visual Analog Scale (VAS) recording at least $60 \mathrm{~mm}$ ] were included in the menus. All these foods and drinks were of known composition and were weighed before and after each meal or snack occasion to the nearest $0.1 \mathrm{~g}$. The energy content and composition of each diet was calculated using the Dutch food composition table [39].

Macronutrient composition (carbohydrate/protein/fat: 55/ $14 / 31$ percentage of energy at $22{ }^{\circ} \mathrm{C}$, and $57 / 14 / 29$ percentage of energy at $27^{\circ}$ ) and energy density (ED, $2.9 \mathrm{~kJ} / \mathrm{g}$ at $22{ }^{\circ} \mathrm{C}$ and $2.7 \mathrm{~kJ} / \mathrm{g}$ at $27{ }^{\circ} \mathrm{C}$ ) were kept at comparable values. The food items were the same at both ambient temperatures and only the amounts were adapted to the energy requirements. ED decreases when offering a lower EI, but still keeping the weight of the food the same. Because ED was not decreased only by water, there was a slight difference in the macronutrient composition.

When the subjects were fed ad lib, they could order any food from the list at any time by telephone. Appetite profiles, i.e., the subjective feelings of motivation to eat, were assessed before and after breakfast, midmorning, before and after lunch, in the afternoon, before and after dinner, and once in the evening, by ratings on 100-mm long anchored VASs [38], with the following questions: How hungry, full, satiated, thirsty are you (anchored: not at all, very)? How much do you estimate you could eat (anchored: nothing/very much)? How is your desire to eat? How is your appetite (anchored: very weak/very strong)? During feeding in EB, appetite was recorded only by VASs [38].

\subsection{Comfort}

Comfort ratings representing general physical wellbeing were monitored nine times in the course of each experimental day using $100 \mathrm{~mm}$ VAS. The questions asked how comfortable, satisfied, irritated, fit the subjects felt, how agreeable the ambient temperature was found, and whether the clothing was found to be adapted to the surrounding temperature (anchored: not at all; very).

\subsection{Data analysis}

To check whether the subjects were in EB, the difference in $24 \mathrm{~h} \mathrm{EE}$ and EI was calculated for each situation (the EB as well as the ad lib situations at both ambient temperatures). Then, the differences between EE and EI were compared with a theoretical difference: 0, indicating no difference between EI and EE, thus a neutral EB.

We compared the periods of $24 \mathrm{~h}$ when the subjects were fed in EB: Day 2 at $27{ }^{\circ} \mathrm{C}$ vs. Day 1 at $22^{\circ} \mathrm{C}$. Separately, we compared the days when they were fed ad lib following a day in EB: Day 2 at $27^{\circ} \mathrm{C}$ (ad lib) vs. Day 2 at $22^{\circ} \mathrm{C}$. The rationale for this was that at $22{ }^{\circ} \mathrm{C}$, habituation with respect to ambient temperature was not necessary, so both days at $22{ }^{\circ} \mathrm{C}$ could be used. However, at $27{ }^{\circ} \mathrm{C}$, the first day was considered as a day for habituation. Therefore, the second days at $27{ }^{\circ} \mathrm{C}$ was used for comparisons, once to compare $\mathrm{EE}$, and once to compare ad lib food intake on a day after having been fed in EB.

Comparisons were made with respect to the following aspects:

- $24 \mathrm{~h} \mathrm{EE} \mathrm{(EE} \mathrm{in} \mathrm{MJ} /$ day) and respiratory quotient (RQ) [36].

- Sleeping metabolic rate (SMR): the lowest mean EE over three consecutive hours between 24:00 and 07:00 h $[33,34,38]$. Accuracy of an individual SMR measurement is given by its standard deviation of the seven measurement points during the three consecutive hours.

- $24 \mathrm{~h}$ DIT: the increase of EE above SMR, corrected for AEE. This was achieved by plotting EE against radar output, for each individual in each session. The intercept of the regression line, at the offset of the radar, thus at zero physical activity, represents the $\mathrm{EE}$ in the inactive state: resting energy expenditure (RMR), consisting of SMR and DIT. The accuracy of RMR is given by the $95 \%$ confidence interval of the individual regression lines.

- DIT was calculated by subtracting SMR from RMR $[23-25,38]$.

- AEE: total EE - RMR [23-25,38] as a function of radar output, corrected for the offset point of the radar. The calculation of AEE based upon the radar output had been validated using a triaxial accelerometer, showing an $r^{2}$ of .9; $P<.0001$ [34]. The $95 \%$ confidence interval of the individual regressions of accelerometer counts and radar output was $2 \pm 1.4 \%$ of AEE [34].

- PAL: $24 \mathrm{~h}$ EE/SMR.

- RQ: $V \mathrm{CO}_{2} / V \mathrm{O}_{2}$.

- Food quotient (FQ) as $V \mathrm{CO}_{2} / V \mathrm{O}_{2}$, when the food consumed is oxidized completely. $\mathrm{O}_{2}$ consumption $(1 /$ day $)=$ $0.966 \times$ protein intake $(\mathrm{g})+2.019 \times$ fat intake $(\mathrm{g})+0.829 \times$ $\mathrm{CHO}$ intake $(\mathrm{g}) . \mathrm{CO}_{2}$ production $(\mathrm{l} /$ day $)=0.774 \times$ protein intake $(\mathrm{g})+1.427 \times$ fat intake $(\mathrm{g})+0.829 \times \mathrm{CHO}$ intake (g) $[40]$.

- The $16 \mathrm{~h}$ averages of the ratings on the components of the appetite profile and of the comfort ratings.

- Body temperatures (rectal and skin temperatures)

During the ad lib feeding days, total EI, EI as a percentage of EE, macronutrient composition of EI, ED [total EI divided by total weight of consumption (including water)] were calculated.

Comparisons were made using ANOVA repeated measures. A multiple regression analysis was executed on the 
possible contributions of changes in body temperature and in EE to possible changes in EI. Statistical analyses were performed using the statistical software program STATVIEW SE + GRAPHICS (Abacus concepts, Berkeley, CA). Outcomes were regarded as statistically different if $P<.05$.

\section{Results}

As indicated before, the comparisons made for the $24 \mathrm{~h}$ EB periods concerned Day 2 at $27{ }^{\circ} \mathrm{C}(\mathrm{EB})$ vs. Day 1 at $22{ }^{\circ} \mathrm{C}$; for the $24 \mathrm{~h}$ ad lib periods this concerned Day 2 at $27{ }^{\circ} \mathrm{C}$ (ad lib) vs. Day 2 at $22{ }^{\circ} \mathrm{C}$.

\subsection{Body weight}

Body weight in the fasting state remained constant at $63.9 \pm 11.0 \mathrm{~kg}$ over each experimental 48 -h period. Moreover, it remained constant over the whole experimental period $(63.8-64.0 \pm 11.5 \mathrm{~kg})$.

\subsection{Body temperature}

In EB, at $27{ }^{\circ} \mathrm{C}$ compared to $22{ }^{\circ} \mathrm{C}$, core $(P<.05)$, proximal and distal $(P<.001)$ skin temperatures had increased (Fig. 1), while the differences between rectal and distal temperatures had decreased $(P<.01)$.

\subsection{Energy balance}

During the $24 \mathrm{~h}$ under EB conditions EI minus EE was $+0.2 \pm 0.7 \mathrm{MJ} /$ day at $22{ }^{\circ} \mathrm{C}$, and $+0.4 \pm 0.3 \mathrm{MJ} /$ day at

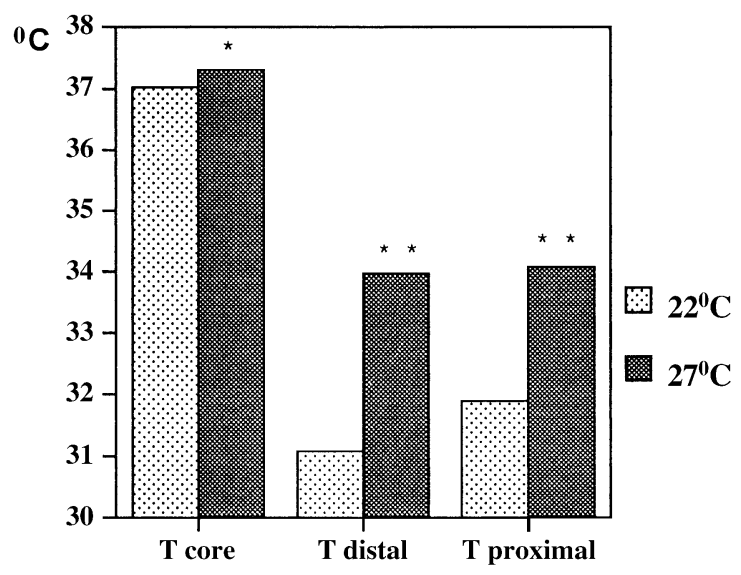

Fig. 1. Average body temperature measured during 2 subsequent days $(16 \mathrm{~h}$ per day) at ambient temperatures of 22 and $27{ }^{\circ} \mathrm{C}$ in women $(n=8) . \mathrm{T}$ core $=$ core temperature $($ rectal $), \mathrm{T}$ distal $=$ distal skin temperature (average of $\mathrm{T}$ hand and $\mathrm{T}$ foot), $\mathrm{T}$ proximal $=$ proximal skin temperature (average of $\mathrm{T}$ forehead, $\mathrm{T}$ thigh, and T collarbone). At 22 and $27{ }^{\circ} \mathrm{C}$, respectively: $\mathrm{T}$ core $37.04 \pm 0.3$ and $37.39 \pm 0.3{ }^{\circ} \mathrm{C}$; $\mathrm{T}$ distal $31.13 \pm 0.6$ and $33.89 \pm 0.3{ }^{\circ} \mathrm{C}$; $\mathrm{T}$ proximal $32.02 \pm 0.4$ and $34.05 \pm 0.35{ }^{\circ} \mathrm{C}$. ${ }^{*} P<.05$; $* * P<.001$, for differences between ambient temperatures.

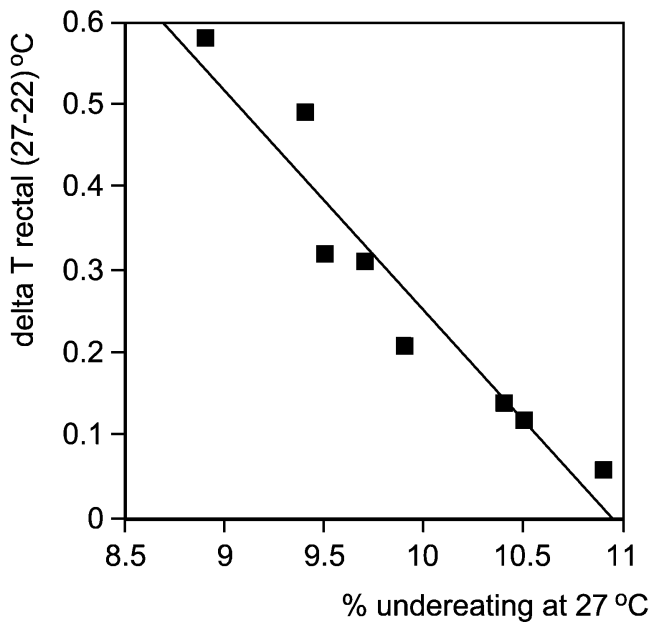

Fig. 2. Relationship between percentage undereating and increase in rectal temperature at $27{ }^{\circ} \mathrm{C}$ in normal-weight women; $n=8 . y=-3 x+3 ; r^{2}=.9$; $P<.001$.

$27{ }^{\circ} \mathrm{C}$, which was neither statistically different from each other, nor statistically different from zero $(P>.5)$, indicating that the subjects were in EB indeed. Moreover, calculated EI from estimated RMR from the HarrisBenedict equation and a PAL of 1.65 were hardly different from the calculation based upon the measured BMR and PAL from the previous day.

On the ad libitum feeding days at both ambient temperatures, the subjects were in a negative EB. At $22{ }^{\circ} \mathrm{C}$ EI was $90.3 \pm 19 \%$ of $\mathrm{EE}$, and at $27^{\circ} \mathrm{C}$ EI was $90.7 \pm 11.3 \%$ of EE $(P=.9)$. The differences between EI and EE were statistically significantly different from $0(P<.01)$, but these differences did not differ between the ambient temperatures $(P>.5)$. At both ambient temperatures ad libitum EI was $90-91 \%$ of EE $(P>.9)$. At $27{ }^{\circ} \mathrm{C}$, percentage undereating was inversely related to the increase of rectal temperature $y=-3 x+3 ; r^{2}=.9 ; P<.001$ (Fig. 2).

\subsection{Energy expenditure}

In EB, $24 \mathrm{~h}$ EE had decreased by $10 \pm 2 \%$ at $27{ }^{\circ} \mathrm{C}$, as compared to that at $22{ }^{\circ} \mathrm{C}(8.9 \pm 1.3 \mathrm{MJ} /$ day vs. $9.9 \pm$ $1.5 \mathrm{MJ} /$ day $)(P<.001)$.

This consisted of a decrease in DIT $(P<.01)$ and in AEE $(P<.01)$, with an almost stable SMR (see Table 1 and Fig. 3). The standard deviation of the individual SMR measurements was between 0.005 and $0.01 \mathrm{MJ} /$ day, indicating an error of $0.2 \pm 0.01 \%$ of SMR. The accuracy of RMR $(\mathrm{SMR}+\mathrm{DIT})$ and of AEE is given by the $95 \%$ confidence interval of the individual regression lines of AEE vs. radar counts, which was $2 \pm 0.1 \%$ of RMR. Adding the square variances, this results in an overall error of $2.6 \%$ of $24 \mathrm{~h}$ EE.

$\mathrm{EE}$ as a function of FFM was significantly lower at $27^{\circ} \mathrm{C}$, compared to that at $22{ }^{\circ} \mathrm{C}(P<.01)$, i.e., the intercept differed significantly, but the slopes did not differ $(r=.9$, for both equations). 
Table 1

24 h EE, SMR, DIT, AEE, PAL, RQ, and FQ of eight lean women during EB with a standardized physical activity protocol and clothing at $27{ }^{\circ} \mathrm{C}$ (Day 2 of EB), compared to at $22{ }^{\circ} \mathrm{C}$ (Day 1)

\begin{tabular}{|c|c|c|}
\hline & $22{ }^{\circ} \mathrm{C}$ & $27{ }^{\circ} \mathrm{C}$ \\
\hline 24 h EE (MJ/day) & $9.9 \pm 1.5$ & $8.9 \pm 1.3 * * *$ \\
\hline SMR (MJ/day) & $5.6 \pm 0.7$ & $5.9 \pm 0.7$ \\
\hline DIT (MJ/day) & $1.0 \pm 0.2$ & $0.7 \pm 0.1^{* *}$ \\
\hline DIT $(\%$ of EI) & $10 \pm 2$ & $7.5 \pm 1$ \\
\hline AEE (MJ/day) & $3.3 \pm 1.0$ & $2.3 \pm 0.6^{* *}$ \\
\hline PAL (24 h EE/SMR) & $1.8 \pm 0.1$ & $1.5 \pm 0.1$ \\
\hline RQ (24 h) & $0.85 \pm 0.02$ & $0.88 \pm 0.02 *$ \\
\hline RQ (12 h day) & $0.86 \pm .01$ & $0.89 \pm 0.02$ \\
\hline RQ (12 h night) & $0.81 \pm 0.03$ & $0.84 \pm 0.04 *$ \\
\hline FQ & $0.88 \pm 0.004$ & $0.88 \pm 0.01$ \\
\hline
\end{tabular}

In the ad libitum feeding situations, EE was not significantly different from $\mathrm{EE}$ during $\mathrm{EB}$, i.e., $9.9 \pm 1.2 \mathrm{MJ} /$ day at $22{ }^{\circ} \mathrm{C}$ and $9.0 \pm 1.1 \mathrm{MJ} /$ day at $27{ }^{\circ} \mathrm{C}$.

The relative DIT was $7.5 \pm 0.9 \%$ at $27{ }^{\circ} \mathrm{C}$, and $10 \pm 2.1 \%$ at $22{ }^{\circ} \mathrm{C}(P<.01)$.

AEE expressed as a function of radar output showed a different slope at $27{ }^{\circ} \mathrm{C}$, compared to that at $22^{\circ} \mathrm{C}(P<.05)$, indicating a higher AEE efficiency at $27^{\circ} \mathrm{C}$, particularly at the relatively higher intensity activities. The radar output corrected for the offset point for the daily activities at both temperatures was on average 4461 counts $/ \mathrm{min}$ at $22{ }^{\circ} \mathrm{C}$, and 4267 counts $/ \mathrm{min}$ at $27{ }^{\circ} \mathrm{C}(P=.4)$, confirming that the daily activities were comparable during both ambient temperatures. During the 30-min bouts of extensive aerobic activity, at both ambient temperatures, rectal temperature increased by $0.2 \pm 0.2{ }^{\circ} \mathrm{C}(P>.05)$. The total increase in EE during this activity was on average $4.5 \pm 1.5 \mathrm{~kJ} / \mathrm{min}$ or $60 \%$ at both ambient temperatures.

Although the food consumed had the same FQ for both ambient temperature conditions, RQ was increased at $27{ }^{\circ} \mathrm{C}$

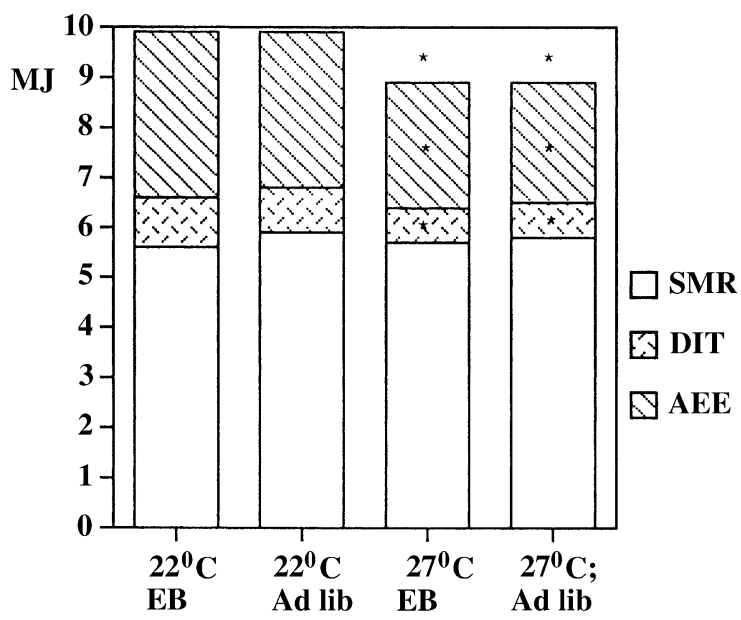

Fig. 3. EE at 22 and $27^{\circ} \mathrm{C}$ in normal-weight women; $n=8$; SMR: sleeping metabolic rate; DIT: diet-induced thermogenesis; AEE: activity-induced energy expenditure. $* P<.01$, compared to the similar day at $22{ }^{\circ} \mathrm{C}$.
(Table 1). This increase appeared to be due to the increase in RQ during the night.

\subsection{Energy intake}

During the 24-h ad libitum feeding situations (Day 2 at $27{ }^{\circ} \mathrm{C}$ ad lib and Day 2 at $22{ }^{\circ} \mathrm{C}$ ), EI was $8.9 \pm 2.0 \mathrm{MJ} /$ day $\left(22{ }^{\circ} \mathrm{C}\right.$ ), and $8.2 \pm 1.4 \mathrm{MJ} /$ day $\left(27{ }^{\circ} \mathrm{C}\right)$, respectively. Decreases in EI were correlated with decreases in EE $(r=.88 ; P<.001)$. The reduction of EI $(10 \pm 3 \%)$ at $27{ }^{\circ} \mathrm{C}$ itself was not statistically significant $(P=.06)$. ED of total consumption (food and drinks) was decreased at $27{ }^{\circ} \mathrm{C}$ by $15 \pm 2 \%$, compared to that at $22{ }^{\circ} \mathrm{C}(P<.01)$. ED was $3.4 \pm 0.4 \mathrm{~kJ} / \mathrm{g}$ at $22{ }^{\circ} \mathrm{C}$ and $2.9 \pm 0.5 \mathrm{~kJ} / \mathrm{g}$ at $27{ }^{\circ} \mathrm{C}$, respectively. At both ambient temperatures, ED was related to EI (at $22{ }^{\circ} \mathrm{C}: r=.83 ; P=.02$, at $27{ }^{\circ} \mathrm{C}: r=.97 ; P=.0001$ ). Moreover, the change in ED was positively related to the change in EI $(r=.8 ; P<0.01)$. Thus, the tendency of a significant reduction in EI $(10 \pm 3 \%)$ was related to the statistically significant reduction in ED $(15 \pm 2 \%)$.

Meal frequency (number of eating occasions/day) remained constant, i.e., three meals and three snacks a day. Neither the macronutrient composition [carbohydrate/ protein/fat: $57 / 13 / 30$ percentage of energy $\left(22^{\circ} \mathrm{C}\right) ; 56 / 14 / 30$ percentage of energy $\left(27^{\circ} \mathrm{C}\right)$ ], nor total weight of consumption (food and drinks) $\left[2.6 \pm 0.7 \mathrm{~kg}\left(22^{\circ} \mathrm{C}\right) ; 2.9 \pm 0.5 \mathrm{~kg}\right.$ $\left.\left(27^{\circ} \mathrm{C}\right)\right]$ was statistically significantly different $(P>.05)$.

At a closer inspection of the selection of food and drinks, it appeared that the decreased ED of food intake at $27{ }^{\circ} \mathrm{C}$ compared to at $22{ }^{\circ} \mathrm{C}$ was due to the following. Although all the food types that were offered were consumed, $40 \pm 2 \%$ of total EI of the lower energy dense foods $(0-7.5 \mathrm{~kJ} / \mathrm{g})$ were consumed instead of $37 \pm 2 \%$ (at $22{ }^{\circ} \mathrm{C}$ ) and $10 \pm 1.5 \%$ of the higher energy dense foods $(15-22.6 \mathrm{~kJ} / \mathrm{g})$ were consumed, instead of $13 \pm 1.5 \%$ (at $22{ }^{\circ} \mathrm{C}$ ). There was no significant difference in the intake of water as such, or of coffee or tea, between both ambient temperatures. The appetite profile did not show any statistically significant

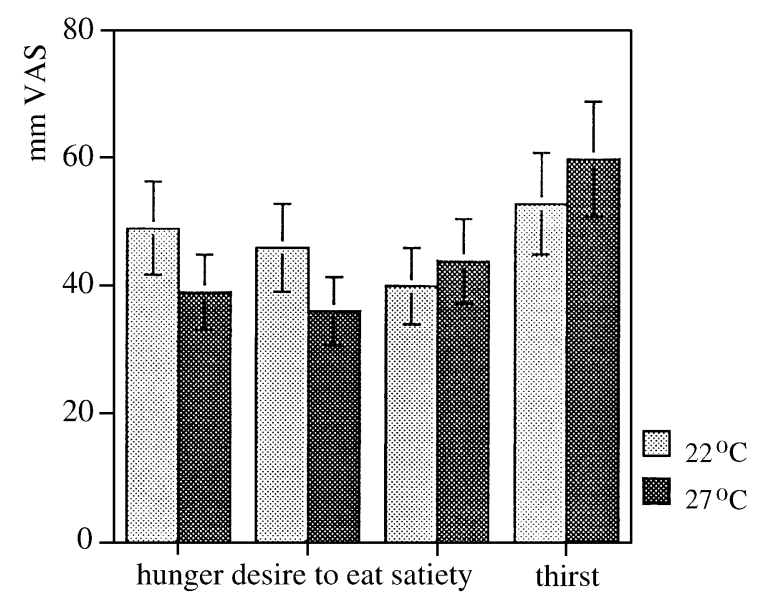

Fig. 4. Average VAS ratings of the appetite profile in normal-weight women at 22 and $27^{\circ} \mathrm{C}$ being fed ad libitum, $n=8$. 
differences between the two days with different temperatures, neither while the subjects were fed in EB, nor when they were fed ad libitum (Fig. 4).

\subsection{Comfort}

Average comfort ratings on the VAS approximated 75, and irritation was low, with no statistically significant differences between the two situations with different ambient temperatures, either with being fed ad libitum, or in EB.

\subsection{Relationship between body temperature or EE and EI}

Multiple regression analyses on the contributions of changes in body temperatures (both rectal and skin temperatures) and $\mathrm{EE}$ to changes in EI and ED showed the following. The reduction in EI and ED at $27{ }^{\circ} \mathrm{C}$, as compared to that at $22{ }^{\circ} \mathrm{C}$, was primarily related to the increase in proximal and distal skin temperatures $(t$ values: proximal temperature: 4.3 ; distal temperature: 4.0 ; both $P<.01)$. Secondarily, the EI and ED reductions were related to the residuals of the regression of EE vs. FFM ( $t$ value: $3.2 ; P<.01)$.

\section{Discussion}

Short-term $(48 \mathrm{~h})$ exposure to an ambient temperature in the thermoneutral zone, i.e., $27^{\circ} \mathrm{C}\left(81^{\circ} \mathrm{F}\right)$ of normal-weight women who were acclimated to an ambient temperature of $22{ }^{\circ} \mathrm{C}\left(72{ }^{\circ} \mathrm{F}\right)$ caused a significant reduction in energy metabolism. This reduction consisted of a reduction in DIT and activity-induced thermogenesis, and a trend of a reduction in EI related to a significant reduction in ED of the food chosen. At the same time, related to this reduction in energy metabolism, rectal and skin body temperatures were increased. Reduction in EE was present when the subjects were fed in EB, while clothing and daily activities were standardized. A tendency to a reduction in EI paralleled the reduction in EE. Despite increases in rectal and skin temperatures at $27{ }^{\circ} \mathrm{C}$, comfort ratings, which were not significantly different between both ambient temperatures, showed that the women felt comfortable at both temperatures. Since the reduced EE showed the same relation with FFM as the original EE did, only the level of EE was reduced at $27{ }^{\circ} \mathrm{C}$. Although $24 \mathrm{~h} \mathrm{EE}$ was reduced at $27^{\circ} \mathrm{C}$, SMR was not. The reduced $\mathrm{EE}$ in the thermoneutral zone is consistent with the findings reported previously [13-20]. The absence of a reduction of SMR seems to be different from some previous findings (i.e. Refs. $[17,19]$ ), reporting a significantly higher BMR at $22{ }^{\circ} \mathrm{C}$, compared to that at $28^{\circ} \mathrm{C}$. This may be due to differences between BMR and SMR measurements. The BMR measurements lasted one [19] or two [17] hours, while the SMR measurements were executed during the three hours of subject-specific lowest EE, also indicated by lowest radar counts, usually between 3:00 and 6:00 a.m. Another reason for the difference in these results might be that in the previous studies subjects were nude, whereas our subjects slept under a duvet. This indicates that the increased BMR at $22{ }^{\circ} \mathrm{C}$ might be due to mild cold whereas finding no difference in SMR might be due to thermal comfort.

$24 \mathrm{~h}$ DIT was reduced at $27^{\circ} \mathrm{C}$, compared to $24 \mathrm{~h} \mathrm{DIT}$ at $22{ }^{\circ} \mathrm{C}$. This concerned the absolute value, which was partly due to the lowered EI, but also the relative value, i.e., the percentage of total EI. At both ambient temperatures, the macronutrient composition of the food was the same, and FQ was the same, so this cannot have affected the DIT [38]. Since the difference in $24 \mathrm{~h}$ DIT cannot completely be explained by the difference in EI, at $27^{\circ} \mathrm{C}$ it was especially the facultative component of DIT being decreased [2426,38]. We defined this part of EE as NST3 [41], being the part of nonshivering thermogenesis that is included in RMR.

$24 \mathrm{~h}$ AEE was reduced, at $27{ }^{\circ} \mathrm{C}$, compared to that at $22{ }^{\circ} \mathrm{C}$, despite the identical and standardized activities protocol under both circumstances. It might be expected that subjects would be less active at higher ambient temperatures, but here we prevented this reaction by the standardized extensive daily-activities program. The similar level of activity is confirmed by the similar radar output. It is possible that less energy has been spent on nonexercise activity thermogenesis (NEAT), and that at $27{ }^{\circ} \mathrm{C}$ activity might be slightly more efficient by a modification in the temperature sensitivity of enzyme activity. EE during moderate aerobic exercise increased moderately by an average of $4.5 \pm 0.5 \mathrm{~kJ} / \mathrm{min}$, or $60 \%$. Larger increases in physical activity are usually accompanied by increases in deep body temperature, closely related to the intensity of work relative to maximum work rate [42] and relatively independent of ambient temperature [43]. We observed a small, statistically nonsignificant increase in the rectal body temperature during the moderate aerobic exercise bouts, at both ambient temperatures, due to the moderate activities the subjects executed. The errors of the measurements of SMR, RMR, and AEE of $0.2 \pm 0.1 \%$ and $2 \pm 0.1 \%$ were smaller than the actual differences in EE of $5.4 \%, 30 \%$, and $30 \%$, respectively. Also, the overall error of $2.6 \%$ was smaller than the difference in total EE of $10 \%$.

$24 \mathrm{~h} \mathrm{RQ}$ was significantly higher at $27{ }^{\circ} \mathrm{C}$ than at $22{ }^{\circ} \mathrm{C}$, due to the $12 \mathrm{~h} R Q$ values during the night. This suggests a temperature or EE dependency of substrate oxidation, i.e., a higher carbohydrate oxidation at higher ambient temperatures, despite identical FQ values. Because $\mathrm{EE}$ is lower at $27{ }^{\circ} \mathrm{C}$ than at $22{ }^{\circ} \mathrm{C}$, the glycogen reserves lasted longer at $27{ }^{\circ} \mathrm{C}$, and therefore RQ did not drop as much as at $22{ }^{\circ} \mathrm{C}$ during the night. Thus, we conclude based upon the decreased energy requirements for DIT and AEE in the thermoneutral zone that in women in EB, while clothing or daily activities are excluded from temperature regulation, DIT and AEE contribute significantly to temperature regulation. There was a tendency for reduction in EI at $27^{\circ} \mathrm{C}$, which was related to the decrease in $\mathrm{EE}$, without a change in the appetite profile or comfort. In the ad libitum feeding 
situation at both ambient temperatures, EI was $90.3-90.7 \%$ of EE $(P=.9)$. It should be noted though that during the 24 -h periods at both ambient temperatures of ad libitum feeding, the subjects were in a negative EB through a decreased EI. However, the energy deficiency was similar, so EI still can be compared between the two ad libitum feeding periods during the different ambient temperatures. The change in EI appeared not to be statistically significant in itself $(P=.06)$, due to the high variability of food intake in the ad libitum feeding situation and to the relatively small number of subjects. The relationship between the decrease in EI and EE was statistically significant, and the change in ED was statistically significant, while ED was related to EI [44].

Both the EI and ED changes were primarily related to the changes in proximal and distal skin temperatures, and secondarily to the change in $\mathrm{EE}$, as was revealed by multiple regression analysis. Moreover, the inverse relation between undereating and increase in rectal temperature showed individual variation in body temperature regulation, in that the less one ate, the less rectal temperature increased. This suggests that food intake regulation by the body is a mechanism of thermoregulation and vice versa. In homeothermic animals, feeding activity might be one of the activities that might be stopped by a thermoregulatory response to prevent hyperthermia in a relatively warm environment [48-51].

The present study shows a similar reduction in EI with increasing temperature $\left(140 \mathrm{~kJ} /{ }^{\circ} \mathrm{C}\right)$ as a result from a previous long-term study [29]. From a field study in which the 50-200 men examined were fully acclimated to the particular environment in which they were living, although clothing and activity were not standardized, a decrease of $125 \mathrm{~kJ} /{ }^{\circ} \mathrm{C}$ was reported [29]. Both this figure and ours are higher than the $60 \mathrm{~kJ} /{ }^{\circ} \mathrm{C}$ reported in a $1950 \mathrm{FAO}$ report [45]. Thus, the reduced $\mathrm{EE}$ at the higher ambient temperature, while executing the same activity protocol and wearing the same clothing, indicates that EI needs to be adapted to prevent a positive EB. This was shown spontaneously in this study, through the decreased ED. It might be expected that thirst ratings would have changed to indicate the decrease in ED of food consumption. During the first rating at $27{ }^{\circ} \mathrm{C}$, before breakfast, thirst was not significantly increased $(P=.10)$, and in the course of the day the nonsignificant difference compared to that at $22{ }^{\circ} \mathrm{C}$ diminished; obviously, the type of consumption was adjusted to the level of thirst.

Food intake at $27{ }^{\circ} \mathrm{C}$ with a reduced ED was not indicated by the appetite profile. Levels of hunger and satiety had not changed at $27{ }^{\circ} \mathrm{C}$, despite ingesting about $10 \%$ less energy than at $22{ }^{\circ} \mathrm{C}$, and despite being in a slightly negative $\mathrm{EB}$. This suggests that the appetite profile was the result and not the cause of food intake. Also, comfort did not affect food intake since these ratings did not differ between the two ambient temperatures. One other study demonstrated that changes in ambient temperature did not modulate feelings of hunger significantly [46]. Some field studies show similar results, i.e., an inverse relation- ship between ambient temperature and food intake during chronic exposure of troops to different climate conditions $[28,29]$, or no correlation between food intake of several groups of military personnel and climate [27]. These studies are based upon self-reported intake of military personnel, and might therefore partly be susceptible to potential errors of underreporting [47].

In conclusion, we have shown that women, in $\mathrm{EB}$, during short-term exposure to the thermoneutral zone, being prevented by adapting clothing or activities, showed an adaptation in EE by decreasing DIT and AEE. The increased RQ at $27{ }^{\circ} \mathrm{C}$ indicated a glycogen sparing effect. A relationship between food intake regulation and thermoregulation is suggested by:

the decrease in EI at $27{ }^{\circ} \mathrm{C}$ (by decreasing ED of foods) during ad lib feeding being primarily related to the increase in skin temperature (proximal and distal); relative undereating at $27{ }^{\circ} \mathrm{C}$ being inversely related to the increase in rectal body temperature.

The question remains whether this short-term adaptation to the thermoneutral zone sustains on the longer term.

\section{Acknowledgments}

We wish to thank Pascale Van Hoydonck and Paul Schoffelen for their help in collecting the data, and Kathleen Melanson for editing the English text.

\section{References}

[1] Benzinger TM. Heat regulation: homeostasis of control temperature in man. Physiol Rev 1969;49:671-759.

[2] Consolazio CF, Matoush L, Le Roy O, Nelson RA. Environmental temperature and energy expenditures. J Appl Physiol 1963;18:65-8.

[3] Johnson JM. Reflex control of skin blood flow by skin temperature: role of core temperature. J Appl Physiol: Respir, Environ Exercise Physiol 1979;47:1188-93.

[4] Kraeuchi K, Wirz-Justice A. Circadian rhythm of heat production, heart rate, and skin and core temperature under unmasking conditions in men. Am J Physiol 1994;267:R819-29.

[5] van Marken Lichtenbelt WD, Westerterp-Plantenga MS, Van Hoydonck P. Individual variation in body temperature and energy expenditure in response to elevated ambient temperature. Physiol Behav 2001;73: 235-42.

[6] Webb P. Temperatures of skin subcutaneous tissue, muscle and core in resting men in cold, comfortable and hot conditions. Eur J Appl Physiol 1992;64:471-6.

[7] Brengelmann GL, Savage MV. Temperature regulation in the neutral zone. Ann NY Acad Sci 1997;813:39-50.

[8] Webb P. Daily activity and body temperature. Eur J Appl Physiol 1993;66:174-7.

[9] Wyss CR, Brengelmann GL, Johnson JM. Control of skin blood flow, sweating and heart rate: role of skin vs core temperature. J Appl Physiol 1974;36:726-33.

[10] Kobayashi S. Temperature-sensitive neurons in the hypothalamus; a new hypothesis that they act as thermostats, not as transducers. Prog Neurobiol 1988;32:103-35. 
[11] Refinetti R. Homeostasis and circadian rhythmicity in the control of body temperature. Ann NY Acad Sci 1997;813:63-70.

[12] Rising R, Keys A, Ravusin E. Concomittant interindividual variation in body temperature and metabolic rate. Am J Physiol 1992;263: E730-4.

[13] Du Bois EF. Basal metabolism in health and disease. 3rd ed. Philadelphia: Lea \& Febiger, 1936.

[14] Hardy JD. Radiation of heat from the human body. An instrument for measuring the radiation and the surface temperature of the skin. J Clin Invest 1934;13:593.

[15] Hardy JD, Du Bois EF. Basal metabolism, radiation, convection and vaporization at temperatures of $22-35{ }^{\circ} \mathrm{C}$. J Nutr 1934;8:695.

[16] Hardy JD, Milhorat AT. Basal heat loss and production in women at temperatures from $23-36^{\circ} \mathrm{C}$. Proc Soc Exp Biol Med 1939;41:94.

[17] Hardy JD, Du Bois EF. Differences between men and women in their response to heat and cold. Proc Natl Acad Sci 1940;26:389-98.

[18] Blaza S, Garrow JS. Thermogenic response to temperature, exercise and food stimuli in lean and obese women, studied by $24 \mathrm{~h}$ direct calorimetry. Br J Nutr 1983;49:171-80.

[19] Dauncey MJ. Influence of mild cold on $24 \mathrm{~h}$ energy expenditure, resting metabolism and diet-induced thermogenesis. Br J Nutr 1981; 45:257-67.

[20] Werner J. Control aspects of human temperature regulation. Automatica 1981;17:351-62.

[21] Bergh U, Ekblom B. Physical performance and peak aerobic power at different body temperatures. J Appl Physiol 1979;46:885-9.

[22] Rothwell NJ, Stock MJ, Stribling D. Diet-induced thermogenesis. In: Schoenbaum E, Lomax P, editors. Thermoregulation, physiology and biochemistry. Section 131. Bowman WC, editor. International encyclopedia of pharmacology and therapeutics. New York: Pergamon, 1990. pp. 309-26.

[23] Pannemans DLE, Bouten CVC, Westerterp KR. 24 h energy expenditure during a standardized activity protocol in young and elderly men. Eur J Clin Nutr 1995;49:49-56.

[24] Ravussin E, Lillioja S, Anderson TE, Christin L, Bogardus C. Determinants of 24-energy expenditure in man. J Clin Invest 1986;78: $1568-78$.

[25] Westerterp KR, Wilson SAJ, Rolland V. Diet induced thermogenesis measured over $24 \mathrm{~h}$ in a respiration chamber: effect of diet composition. Int J Obes Relat Metab Disord 1998;22:1-6.

[26] Westerterp-Plantenga MS, Wouters L, ten Hoor F. Deceleration in cumulative food intake curves, changes in body temperature and diet-induced thermogenesis. Physiol Behav 1990;48:831-6.

[27] LeBlanc JA. Effect of environmental temperature on energy expenditure and caloric requirements. J Appl Physiol 1957;10:281-3.

[28] Edholm OG, Goldsmith R. Food intakes and weight changes in climatic extremes. Proc Nutr Soc 1966;25:113-9.

[29] Johnson RE, Kark RM. Environment and food intake in man. Science 1947;105:378-9.

[30] Siri WE. Body composition from fluid density: analysis of methods. In: Brozek J, Herschel A, editors. Techniques for measuring body composition. Washington (DC): National Academy of Sciences, National Research Council, 1961. pp. 233-44.

[31] Stunkard AJ, Messick S. The Three Factor Eating Questionnaire to measure dietary restraint, disinhibition and hunger. Psychiatr Res 1985;29:71-83.

[32] Westerterp-Plantenga MS, van den Heuvel E, Wouters L, ten Hoor F.
Restrained eating, obesity and cumulative food intake curves during four-course meals. Appetite 1991;16:149-58.

[33] Schoffelen PFMA, Westerterp KR, Saris WHM, ten Hoor F. A dual respiration chamber system with automated calibration. J Appl Physiol 1997;83:2064-72.

[34] Bouten CVC, Pannemans DLE, Westerterp KR, Verduin M. Physical activity assessment during standardized activity in a respiration chamber: movement registration versus energy expenditure. Int J Obes Relat Metab Disord 1995;19:29.

[35] ISO 9920. Ergonomics of the thermal environment - estimation of the thermal insulation and evaporative resistance of a clothing ensemble. Geneve: IOS, 1995.

[36] Weir JBDV. New methods for calculating metabolic rate with special reference to protein metabolism. J Physiol 1949;109:1-9.

[37] Harris JA, Benedict FG. A biometric study of basal metabolism in man, vol. 279 Washington (DC): Carnegie Institute, 1919. pp. 1-266.

[38] Westerterp-Plantenga MS, Rolland V, Wilson SAJ, Westerterp KR. Satiety related to $24 \mathrm{~h}$ diet-induced thermogenesis during high protein/carbohydrate vs high fat diets measured in a respiration chamber. Eur J Clin Nutr 1999;53:495-502.

[39] Voorlichtingsbureau voor de Voeding. De handleiding van de Voedingswijzer, Den Haag, 1992.

[40] Jequier E, Schutz Y. Long term measurements of energy expenditure in humans using a respiration chamber. Am J Clin Nutr 1983;38: 989-98.

[41] Westerterp-Plantenga MS, van Marken Lichtenbelt WD, Schrauwen P. Core-skin gradient of body temperature related to non-shivering thermogenesis 3 in humans at a lowered ambient temperature. J Therm Biol 2001;26:467-72.

[42] Saltin B, Hermansen L. Esophageal, rectal and muscle temperature during exercise. J Appl Physiol 1966;21:1757-62.

[43] Nielsen M. Die Regulation der Koerpertemperatur durch Muskelarbeit. Scand Arch Physiol 1938;79:193-230.

[44] Westerterp-Plantenga MS. Analysis of energy density of food in relation to energy intake regulation in human subjects. Br J Nutr 2001; $85: 351-61$.

[45] Food and Agriculture Organization of the United Nations. Caloric requirements. United Nations, Report of the Committee on Caloric Requirements.Washington, DC: FAO, 1950.

[46] Russek M, Fantino M, Cabanac M. Effect of environmental temperature on pleasure ratings of odors and tastes. Physiol Behav 1979; 22:251-6.

[47] Goris AHC, Westerterp-Plantenga MS, Westerterp KR. Undereating and underrecording of habitual food intake in obese men; selective underreporting of fat intake. Am J Clin Nutr 2000;71:130-4.

[48] Johnson KG, Cabanac M. Homeostatic competition between food intake and temperature regulation in rats. Physiol Behav 1982;28: $675-9$.

[49] Brobeck JR. Food intake as a mechanism of temperature regulation. Obes Res 1955;5:641-4.

[50] De Vries J, Strubbe JH, Wildering WC. Patterns of body temperature during feeding in rats under varying ambient temperatures. Physiol Behav 1993;53:229-35.

[51] Zhao X-Q, Jorgensen H, Gabert VM. Energy metabolism and protein balance in growing rats housed in $18{ }^{\circ} \mathrm{C}$ or $28{ }^{\circ} \mathrm{C}$ environments and fed different levels of dietary protein. J Nutr 1996;126: 2036-43. 